\title{
Characterization of ghrelin receptor activity in a rat pituitary cell line RC-4B/C
}

\author{
H Douglas Falls, Brian D Dayton, Dennis G Fry, Christopher A Ogiela, Verlyn G Schaefer, \\ Sevan Brodjian, Regina M Reilly, Christine A Collins and Wiweka Kaszubska
}

Metabolic Disease Research, Global Pharmaceutical Products Division, Abbott Laboratories, R4MJ, Bldg. AP9A, 100 Abbott Park Road, Abbott Park, Illinois 60064-6099, USA

(Requests for offprints should be addressed to D G Fry; Email: dennis.fry@abbott.com)

(Current address of W Kaszubska is Corporate Global Product Development, Serono International, S.A., 15bis, chemin des Mines, 1211 Geneva, Switzerland)

\begin{abstract}
Ghrelin, a 28 amino acid, octanoylated peptide, is an endogenous ligand for the growth hormone secretagogue receptor (GHS-R). In addition to various endocrine functions, including stimulation of $\mathrm{GH}$ release, ghrelin has been characterized as an important regulator of energy homeostasis. Ghrelin administration has been shown to increase adiposity in rodents and stimulate food intake in humans. Studies suggest that these orexigenic effects are mediated primarily through GHS-R expression in hypothalamic and pituitary neuronal pathways. In this context, GHS-R has been recognized as a potential target for the treatment of GH deficiency and body weight disorders. Cell lines provide convenient in vitro systems to identify and characterize potential pharmacophores and to analyze GHS-R functional activity. While recombinant cell lines that overexpress GHS-R have served as effective research tools for these studies, such cell lines may differ in signaling response to ghrelin compared with hypothalamic or pituitary cells expressing GHS-R. We show here that a cell line derived from a rat anterior pituitary adenoma, $\mathrm{RC}-4 \mathrm{~B} / \mathrm{C}$, expresses endogenous $\mathrm{GHS}-\mathrm{R}$ as judged by reverse transcriptase-PCR. In a Ca ${ }^{2+}$ mobilization assay, $\mathrm{RC}-4 \mathrm{~B} / \mathrm{C}$ cells demonstrate a dose-dependent increase in intracellular $\left[\mathrm{Ca}^{2+}\right]$ on stimulation with rat ghrelin and a related peptide agonist, hexarelin $\left(\mathrm{EC}_{50}, 1.0 \mathrm{nM}\right.$ and $1.7 \mathrm{nM}$ respectively), but are unresponsive to treatment with inactive des-octanoyl rat ghrelin. A subclone, RC-4B/C.40, with a more robust and stable ghrelin response, was isolated from the parental population of cells to allow further analysis of GHS-R signal transduction. Using pertussis toxin and the phospholipase $\mathrm{C}$ inhibitor U-73122, we show that ghrelin signals through the Gq pathway in the RC-4B/C.40 cells. We also demonstrate that the ghrelin-induced rise of intracellular $\left[\mathrm{Ca}^{2+}\right]$ in $\mathrm{RC}$ 4B/C. 40 cells involves initial $\mathrm{Ca}^{2+}$ release from intracellular stores followed by a sustained elevation that occurs via influx of extracellular $\mathrm{Ca}^{2+}$ through ion channels. In addition, unlike observations reported in recombinant cell systems, the RC-4B/C.40 cells do not exhibit a high level of GHS-R constitutive activity as determined in a phosphatidylinositol hydrolysis assay. Overall, the data presented here suggest that the RC-4B/C parental and RC-4B/C.40 cells provide novel in vitro systems for the characterization of GHS-R pharmacophores and ghrelin signaling.
\end{abstract}

Journal of Molecular Endocrinology (2006) 37, 51-62

\section{Introduction}

The pulsatile secretion of growth hormone $(\mathrm{GH})$ by the anterior pituitary is a complex process governed mainly by two hypothalamic hormones (Giustina \& Veldhuis 1998), growth hormone-releasing hormone (GHRH) and its counter-regulatory hormone, somatostatin. In addition, there are synthetic, peptidyl, and non-peptidyl molecules termed GH secretagogues (GHSs) known to possess growth hormone-releasing activity (Smith $\mathrm{et} \mathrm{al}$. 1997). These molecules were first described 20 years ago in efforts to develop alternative treatments for GH deficiency. They were recently shown to act through the GH secretagogue receptor (GHS-R) (Howard et al. 1996, Smith et al. 1996). GHSs and GHRH have synergistic effects, indicating that they probably act via different mechanisms (Smith et al. 1997, Ghigo et al. 2001).
Recently, a natural ligand for GHS-R was identified. Ghrelin is a 28-amino acid, octanoylated peptide secreted primarily by the upper intestinal tract (Kojima et al. 1999). It is a potent dosedependent GHS in rodents (Saito et al. 2003) and humans (Peino et al. 2000, Takaya et al. 2000). However, ghrelin function is not restricted to $\mathrm{GH}$ release, as it has been shown to be an important regulator of food intake and body weight (Horvath et al. 2003). Ghrelin plasma levels rise before meals and fall following feeding (Cummings et al. 2001). Ghrelin infusion in near-physiological doses increases hunger in humans (Wren et al. 2001) and adiposity in rodents (Tschöp et al. 2000). Consistent with high sequence homology to motilin, ghrelin stimulates gastric contractility and acid secretion (Masuda et al. 2000).

DOI: $10.1677 /$ jme.1.01943 Online version via http://www.endocrinology-journals.org 
Although ghrelin was isolated and purified from the oxyntic mucosa of the stomach (Kojima et al. 1999, Date et al. 2000), it is produced in other tissues, albeit at lower levels. These include not only the hypothalamus (Cowley et al. 2003) and pituitary (Korbonits et al. 2001), the sites of GHS-R expression, but also the pancreas, kidney, liver, heart, lung, ovary, prostate, and the placenta (Gnanapavan et al. 2002). The full-length ghrelin receptor, GHS-R1a, is expressed mainly in the GH-producing cells of the pituitary (Adams et al. 1998, Korbonits et al. 1998, Skinner et al. 1998, Korbonits et al. 2001). It is also found in the hypothalamus where it is thought to mediate the orexigenic (appetite stimulating) effects of ghrelin in addition to stimulating GHRHneurons (Howard et al. 1996). Recently, GHS-R expression has also been identified in afferent vagal neurons. It was shown that ghrelin-induced increase of feeding in rats is dependent on an intact vagal nerve (Date $e t$ al. 2002). Therefore, ghrelin appears to be a physiological link between the stomach, the pituitary, and the hypothalamus.

GHS-R expression and activity have been well characterized in a variety of cell systems (Smith et al. 1997, Kojima et al. 1999). Activation of the receptor by ghrelin, peptidomimetics or small-molecule agonists is coupled via $\mathrm{G} \alpha_{\mathrm{q}}$-proteins to the phospholipase $\mathrm{C}$ pathway, leading to inositol trisphosphate (IP) and diacylglycerol (DAG) production. The elevation of IP produces a subsequent increase in cytosolic intracellular $\mathrm{Ca}^{2+}$ concentration $\left(\left[\mathrm{Ca}^{2+}\right]_{\mathrm{i}}\right)$ from intracellular stores. In parallel, DAG stimulates protein kinase C (PKC), leading to activation of the mitogenactivated protein kinase (MAPK) pathway. The MAPK pathway has been identified as responsible for mitogenic and antiapoptotic effects of ghrelin (Kim et al. 2004, Nanzer et al. 2004). GHS-R activation also results in activation of L-type $\mathrm{Ca}^{2+}$ channels and influx of $\mathrm{Ca}^{2+}$ from the extracellular milieu (Smith et al. 1997, Glavaski-Joksimovic et al. 2003).

There is substantial evidence that GHS-R in such systems displays a high level of constitutive activity (Holst et al. 2003, 2004, Holst \& Schwartz 2004). While treatment with inverse agonists such as substance $\mathrm{P}$ and related analogs has been shown to effectively suppress this activity, it remains to be determined whether the constitutive activity seen in recombinant GHS-R expression has physiological relevance in vivo.

As cell lines are much more convenient for receptor pharmacology studies than either primary cell preparations or direct in vivo studies, our aim was to identify and characterize the functional activity of endogenously expressed GHS-R in a physiologically relevant cell line. We reasoned that such a cell line might provide a useful intermediate between recombinant cell lines and primary cell preparations for elucidating GHS-R signaling. We identified RC-4B/C cells (Hurbain- Kosmath et al. 1990) derived from an anterior pituitary adenoma of a male rat as a suitable in vitro system for this purpose. We demonstrate here that $\mathrm{RC}-4 \mathrm{~B} / \mathrm{C}$ cells respond to ghrelin treatment with an increase in $\left[\mathrm{Ca}^{2+}\right]_{\mathrm{i}}$ that is blocked by GHS-R antagonists. Additionally, we isolated a subclone of the parental RC-4B/C cells, RC-4B/C.40, which demonstrated a more robust and stable ghrelin response in a $\mathrm{Ca}^{2+}$ mobilization assay. As a more homogeneous cell population with enhanced GHS-R expression, the subclone allowed for further analysis of ghrelin signaling, including characterization of the ghrelininduced $\mathrm{Ca}^{2+}$ pathways. It appears that the RC-4B/C.40 cells signal through $\mathrm{G}_{\mathrm{q}}$ in a manner similar to Chinese hamster ovary (CHO)-K1 cells expressing human GHS-R (CHO-hGHS-R). However, when using a phosphatidylinositol (PI) hydrolysis assay, we did not observe the level of constitutively active GHS-R in the RC-4B/ C.40 cells that occurs in the recombinant $\mathrm{CHO}$ line. This observation seems particularly interesting in that it may be the first reported example of a nonconstitutively active, functional GHS-R in a relevant pituitary cell line. Overall, our results indicate that $\mathrm{RC}-4 \mathrm{~B} / \mathrm{C}$ parental and RC-4B/C.40 cells are potentially useful in vitro systems for the characterization of GHS-R agonists and antagonists. Furthermore, these cell lines may provide a better model of ghrelin signaling in vivo.

\section{Materials and methods}

\section{Cell culture}

CHO-hGHS-R (Euroscreen s.a. Brussels, Belgium) were cultured in Ultra-CHO medium from Cambrex Bio Science (Walkersville, MD, USA) supplemented with $1 \%$ dialyzed fetal bovine serum (FBS), $50 \mu \mathrm{g} / \mathrm{ml}$ gentamicin, and $400 \mu \mathrm{g} / \mathrm{ml}$ G418 (all from Invitrogen) at $37^{\circ} \mathrm{C}$ in a humidified cell incubator containing $5 \%$ $\mathrm{CO}_{2}$. Rat pituitary adenoma cells, RC-4B/C (CRL-1903; ATCC, Manassas, VA, USA), were cultured in a 1:1 mixture of Dulbecco's Modified Eagle's Medium (Sigma) and Minimum Essential Alpha Medium (Invitrogen) supplemented with $0.01 \mathrm{mM}$ non-essential amino acids (Sigma), $15 \mathrm{mM}$ HEPES (Sigma), $2.5 \mathrm{ng} / \mathrm{ml}$ epidermal growth factor (Invitrogen), and $10 \%$ dialyzed, heat-inactivated $\mathrm{FBS}$ at $37^{\circ} \mathrm{C}$ in a humidified cell incubator containing $5 \% \mathrm{CO}_{2}$. Subcloning of the parental population was performed by limiting dilution cloning in 96-well tissue culture plates using a conditioned RC-4B/C media. Conditioned media was prepared by incubation on a confluent monolayer of RC-4B/C cells for $24 \mathrm{~h}$, after which time the media was decanted, filtered through a $0.22 \mu \mathrm{m}$ filter, and stored at $4{ }^{\circ} \mathrm{C}$ until use. 


\section{Reagents}

GHS-R agonist hexarelin (His-D-2-methyl-Trp-Ala-Trp-DPhe-Lys) was purchased from American Peptide Inc. (Sunnyvale, CA, USA), rat ghrelin (Gly-Ser-Ser ( $n$ octanoyl)-Phe-Leu-Ser-Pro-Glu-His-Gln-Lys-Ala-GlnGln-Arg-Lys-Glu-Ser-Lys-Lsy-Pro-Pro-Ala-Lys-Leu-GlnPro-Arg) was synthesized at Abbott, and rat des-octanoyl ghrelin was either purchased from Phoenix Pharmaceuticals Inc. (Belmont, CA, USA) or synthesized at Abbott. GHS-R antagonist [D-Lys3]-GHRP-6 (H-His-DTrp-D-Lys-Trp-D-Phe-Lys) and the inverse agonist (D-Arg ${ }^{1}$, D-Phe ${ }^{5}$, D-Trp ${ }^{7,9}$, Leu $\left.^{11}\right)$-substance $\mathrm{P}$ analog were purchased from Bachem Bioscience Inc. (King of Prussia, PA, USA). The PLC inhibitor U-73122 was purchased from BIOMOL. Thapsigargin was purchased from Alexis Biochemicals (Lausen, Switzerland). $\left[{ }^{3} \mathrm{H}\right]$ myoinositol was purchased from Perkin-Elmer (Shelton, CT, USA). AG1-X8 anion-exchange resin columns were purchased from Bio-Rad. The L-type calcium channel blocker nifedipine, Ptx, and myoinositol were purchased from Sigma. Compounds A and B were synthesized at Abbott.

\section{Reverse transcriptase PCR (RT-PCR)}

Total RNA was isolated from cell pellets using TRIreagent (Sigma) according to the manufacturer's specifications. First-strand cDNA was generated using the SuperScript First-Stand Synthesis System (Invitrogen) with oligo (dT) primers and $5 \mu \mathrm{g}$ total RNA. The target cDNA was then amplified by PCR. The reaction contained $10 \times \mathrm{PCR}$ buffer (Invitrogen), $200 \mathrm{nM}$ dNTP mix, $1.5 \mathrm{mM} \mathrm{MgCl}_{2}, 200 \mathrm{nM}$ primers to human GHS-R1a, 5'TCTTCCTTCCTGTCTTCTGTC3' (sense) and 5'AGTCTGAACACTGCCACC3' (antisense), and platinum Taq DNA polymerase (Invitrogen) in $50 \mu \mathrm{l}$ total volume. Thermal cycling consisted of 5 min at $95^{\circ} \mathrm{C}$ followed by 40 cycles of $30 \mathrm{~s}$ at $95^{\circ} \mathrm{C}, 30 \mathrm{~s}$ at $50{ }^{\circ} \mathrm{C}, 2 \mathrm{~min}$ at $72^{\circ} \mathrm{C}$, and was concluded with $10 \mathrm{~min}$ at $72^{\circ} \mathrm{C}$.

\section{Fluorescent calcium indicator (FLIPR) assay}

\section{Agonist $E C_{50}$ /antagonist $I C_{50}$ determinations}

RC-4B/C parental or RC-4B/C.40 cells were plated in black 96-well plates with clear bottoms (Corning Inc. Corning, NY, USA) and cultured to confluency overnight in growth medium at $37^{\circ} \mathrm{C}$ in a humidified cell incubator containing $5 \% \mathrm{CO}_{2}$. Growth medium was replaced with $100 \mu \mathrm{l}$ Dulbecco's PBS (DPBS) containing $1000 \mathrm{mg} / 1 \mathrm{D}$-glucose, $36 \mathrm{mg} / 1$ sodium pyruvate (Invitrogen) supplemented with $1 \cdot 14 \mathrm{mM}$ Fluo-4 AM (Molecular Probes, Eugene, OR, USA) and $2.5 \mathrm{mM}$ probenecid (Sigma) for 1-3 $\mathrm{h}$ in the dark at room temperature. For $\mathrm{EC}_{50}$ determinations, various concentrations of agonist were prepared at $4 \times$ final concentrations in DPBS containing $0 \cdot 1 \%$ BSA.

After aspirating the dye solution, cells were washed three times in DPBS using an $\mathrm{EL}_{\mathrm{x}}-405$ Automatic Plate Washer (Bio-Tek Instruments, Winooski, VT, USA). Following the last wash, cells were placed in $150 \mu \mathrm{l} /$ well of DPBS and the plates were then transferred to the FLIPR unit (Molecular Probes) where $50 \mu \mathrm{l}$ of $4 \times$ agonist doses were added and the agonist-induced rise of $\left[\mathrm{Ca}^{2+}\right]_{\mathrm{i}}$ detected by Fluo-4AM fluorescence was followed for $3 \mathrm{~min}$. Fluorescence emissions from 96 wells were measured simultaneously at excitation and emission wavelengths of 488 and $520 \mathrm{~nm}$ respectively for 3 min in 1-s intervals for the first minute and 5-s intervals thereafter. Agonist activity was thus expressed as percent activation with an $\mathrm{EC}_{50}$ being the concentration of agonist causing a $50 \%$ activation of a maximal ghrelin response. For $\mathrm{IC}_{50}$ determinations, after loading with dye solution, washing, and replacing with $100 \mu \mathrm{l}$ DPBS, cell plates were placed in FLIPR where $50 \mu \mathrm{l}$ /well of $4 \times$ antagonist concentrations were added and measurements taken for 3-6 min, followed by the addition of $50 \mu \mathrm{l} /$ well of $4 \times$ ghrelin ligand in DPBS $/ 0 \cdot 1 \%$ BSA (final concentration of 3 or $10 \mathrm{nM}$ for RC-4B/C cells and $1 \mathrm{nM}$ for CHO-hGHS-R cells). Fluorescence measurements were then taken for another $3 \mathrm{~min}$. $\mathrm{IC}_{50} \mathrm{~s}$ were determined as the concentration of antagonist causing a $50 \%$ reduction of the ghrelin-induced calcium signal. Sigmoidal curves were fitted by GraphPad Prism software (GraphPad Software, Inc., San Diego, CA, USA) and $\mathrm{EC}_{50}$ or $\mathrm{IC}_{50}$ values were calculated based on results from triplicate determinations.

\section{Effects of pertussis (Ptx)}

RC-4B/C.40 cells were exposed to $1000 \mathrm{ng} / \mathrm{ml}$ Ptx for $4 \mathrm{~h}, 37^{\circ} \mathrm{C}$. At the end of the $4 \mathrm{~h}$ incubation, the culture medium was aspirated, $100 \mu \mathrm{l}$ DPBS containing glucose and pyruvate were added to each well along with $100 \mu \mathrm{l}$ calcium assay reagent (Molecular Devices, Sunnyvale, CA, USA) containing $2.5 \mathrm{mM}$ probenecid. Cells were analyzed in the FLIPR for their response to rat ghrelin as described in the previous subsection.

\section{Effects of extracellular and intracellular $\mathrm{Ca}^{2+}$}

The role of extracellular $\mathrm{Ca}^{2+}$ in ghrelin signaling in RC-4B/C.40 cells was determined as described above, except that after loading with Fluo-4 AM dye solution, cells were washed a minimum of three times in $\mathrm{Ca}^{2+} / \mathrm{Mg}^{2+}$-free DPBS, and then stimulated with rat ghrelin in either standard $\mathrm{Ca}^{2+} / \mathrm{Mg}^{2+}$-containing or $\mathrm{Ca}^{2+} / \mathrm{Mg}^{2+}$-free DPBS. To further define the role of extracellular $\mathrm{Ca}^{2+}$, cells were also pretreated with the L-type calcium channel blocker, nifedipine. Briefly, after washing three times in $\mathrm{Ca}^{2+} / \mathrm{Mg}^{2+}$-free DPBS, 
cells were transferred to the FLIPR unit where $150 \mu \mathrm{l}$ of a $1.5 \times$ dose of nifedipine was added (for a final concentration of $100 \mu \mathrm{M})$, and the signal was monitored for $6 \mathrm{~min}$. Following pretreatment with nifedipine, cells were stimulated with $10 \mathrm{nM}$ ghrelin and the effects on $\left[\mathrm{Ca}^{2+}\right]_{\mathrm{i}}$ were monitored for an additional $3 \mathrm{~min}$. To assess the role of $\mathrm{Ca}^{2+}$ release from intracellular stores, RC-4B/C.40 cells were washed in $\mathrm{Ca}^{2+} / \mathrm{Mg}^{2+}$-free DPBS and pretreated with $1 \mu \mathrm{M}$ thapsigargin in $\mathrm{Ca}^{2+} / \mathrm{Mg}^{2+}$-free DPBS (causing $\mathrm{Ca}^{2+}$ release from intracellular stores and preventing re-uptake into the endoplasmic reticulum). The thapsigargin-induced release of intracellular $\mathrm{Ca}^{2+}$ was monitored in FLIPR for a minimum of 6 min (allowing for the return of signal to baseline). Cells were then stimulated with rat ghrelin in either $\mathrm{Ca}^{2+} / \mathrm{Mg}^{2+}$-free or $\mathrm{Ca}^{2+} / \mathrm{Mg}^{2+}$-containing DPBS. The ghrelin-induced fluorescence signal was monitored on FLIPR for an additional $5 \mathrm{~min}$. The resultant fluorescent signal tracings were normalized to the basal signal in $\mathrm{Ca}^{2+} / \mathrm{Mg}^{2+}$-free DPBS using FLIPR software and further analyzed in GraphPad Prism (GraphPad Software).

\section{PI hydrolysis assay}

The constitutive activity of GHS-R in RC-4B/C.40 and CHO-hGHS-R cells was determined using a PI hydrolysis assay that measures the accumulation of $\left[{ }^{3} \mathrm{H}\right]$ inositol phosphates following activation of GHS-R. Briefly, cells were seeded at $5 \times 10^{5}$ cells/well in 24-well plates and cultured for $24 \mathrm{~h}$. Cells were then labeled for $16-18 \mathrm{~h}$ with $\left[{ }^{3} \mathrm{H}\right]$ myoinositol $(2 \mu \mathrm{Ci} /$ well $)$. After washing with room temperature DPBS, cells were treated with $200 \mu \mathrm{l} /$ well of $10 \mathrm{mM} \mathrm{LiCl}$ in Earle's/25 mM HEPES $/ 0 \cdot 0073 \mathrm{mM}$ pepstatin/0.1 mM PMSF buffer for $45-60 \mathrm{~min}$ at $37^{\circ} \mathrm{C}$ in a $5 \% \mathrm{CO}_{2}$ incubator to block endogenous inositol mono-phosphatase activity. Next, cells were stimulated with either ghrelin or $\left[\mathrm{D}-\mathrm{Arg}^{1}, \mathrm{D}-\mathrm{Phe}^{5}, \mathrm{D}-\mathrm{Tryp}^{7,9}, \mathrm{Leu}^{11}\right]$-substance P analog for $30 \mathrm{~min}$ at $37^{\circ} \mathrm{C}$. Cells were lysed by the addition of $50 \mu \mathrm{l} /$ well of $1 \mathrm{~N} \mathrm{NaOH}$ followed by an equal volume of $1 \mathrm{~N} \mathrm{HCl}$. Samples were then transferred to $12 \times 75 \mathrm{~mm}$ glass tubes, extracted by adding $1.5 \mathrm{ml} /$ tube of chloroform/methanol $(1: 2, \mathrm{v} / \mathrm{v})$, vortexed gently, and incubated for $1 \mathrm{~h}$ at room temperature. Additional $0.5 \mathrm{ml} /$ tube volumes of chloroform were added followed by $0.4 \mathrm{ml} /$ tube of double distilled(dd) $\mathrm{H}_{2} \mathrm{O}$. Following centrifugation at $1100 \mathrm{~g}$ for $20 \mathrm{~min}$ at room temperature, the aqueous phase was diluted to $3 \mathrm{ml}$ with $\mathrm{ddH}_{2} \mathrm{O}$. Samples were loaded onto AG1-X8 columns and washed with $20 \mathrm{ml}$ ice-cold, non-radioactive myoinositol, followed by $6 \mathrm{ml} 60 \mathrm{mM}$ sodium formate $/ 5 \mathrm{mM}$ sodium tetraborate. The $\left[{ }^{3} \mathrm{H}\right]$ inositol phosphate fraction was eluted with $5 \mathrm{ml} 1 \mathrm{M}$ ammonium formate $/ 0 \cdot 1 \mathrm{~N}$ formic acid. Total counts per minute $(\mathrm{CPM})$ were determined in a Beckman LS 6500 scintillation counter.

\section{Results}

\section{GHS-R mRNA expression in RC-4B/C cells}

A single product of the expected size (349 bp) was generated by RT-PCR using cDNA derived from the RC-4B/C cell line (Fig. 1, lane c). The corresponding negative control reaction lacking the RT did not yield any products (Fig. 1, lane d), thus ruling out potential contamination by genomic DNA in the RNA isolation. PC3, a prostate cancer cell line that was previously shown to express GHS-R (Volante et al. 2002), yielded a product of expected size (Fig. 1, lane b). In addition, cDNA from CHO-GHS-R cells and a vector encoding GHS-R1a were used as positive controls. Taken together, these observations suggest that $\mathrm{RC}-4 \mathrm{~B} / \mathrm{C}$ cells express GHS-R1a mRNA.

\section{$\mathrm{Ca}^{2+}$ Flux response to GHS-R agonists and antagonists}

\section{$R C-4 B / C$ parental cells}

We next investigated whether the $\mathrm{RC}-4 \mathrm{~B} / \mathrm{C}$ cell line, expressing an endogenous GHS-R1a, could be used as a reagent for screening of GHS-R agonists and antagonists in vitro. To determine the functional activity of GHS-R, we measured $\left[\mathrm{Ca}^{2+}\right]_{\mathrm{i}}$ using fluorescence imaging. RC4B/C cells were treated with ghrelin, hexarelin, and desoctanoyl ghrelin, an inactive form of ghrelin serving as a negative control. These peptides were tested at half-log concentrations and their activity expressed as percent maximal activation. Both ghrelin and hexarelin demonstrated a robust dose-dependent response in the $\mathrm{RC}-4 \mathrm{~B} / \mathrm{C}$ cells with $\mathrm{EC}_{50}$ values of $1.04 \mathrm{nM}$ and $1 \cdot 67 \mathrm{nM}$ respectively (Fig. 2A). Des-octanoylated ghrelin, on the other hand, did not elicit a signal at any of the doses tested (Fig. 2A), indicating that the ghrelin response in the $\mathrm{RC}-4 \mathrm{~B} / \mathrm{C}$ cells is specific to its active form. We also tested the effects of GHS-R antagonists in this assay. Preincubation of $\mathrm{RC}-4 \mathrm{~B} / \mathrm{C}$ cells with a known peptidyl antagonist [D-Lys-3]-GHRP-6 and compound A resulted in a dose-dependent inhibition

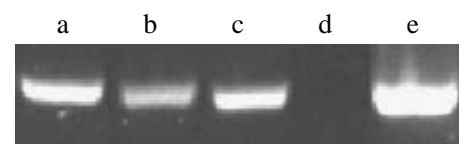

Figure 1 GHS-R1a mRNA expression in various cell lines. RT-PCR products amplified from (a) CHO-hGHS-R cells, (b) PC3 cell line, (c) RC-4B/C cell line, (d) negative control, RC-4B/C total RNA preparation without the addition of reverse transcriptase, (e) positive control, vector encoding the human GHS-R1a gene. 

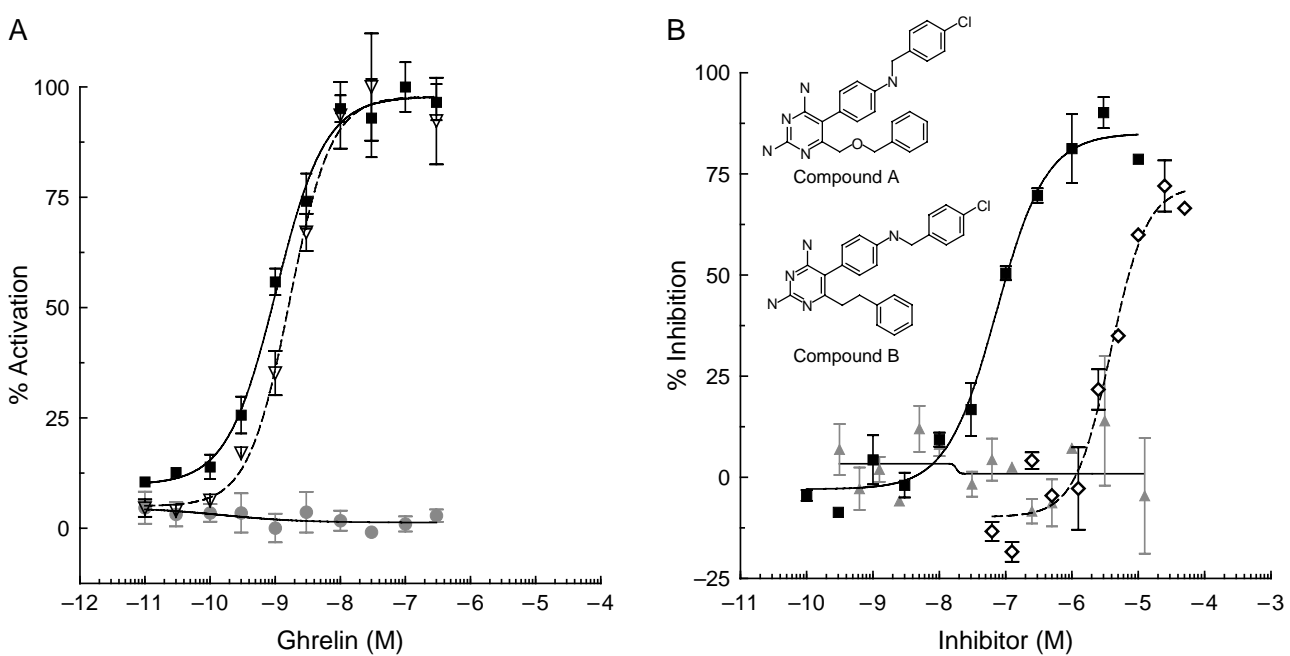

Figure 2 Effects of GHS-R agonists and antagonists in RC-4B/C cells. (A) Agonist effects - cells were treated with various concentrations of ghrelin $(\boldsymbol{\square})$, hexarelin $(\nabla)$, and des-octanoyl ghrelin $(\bullet)$, and their effects on $\left[\mathrm{Ca}^{2+}\right]_{\mathrm{i}}$ were measured by fluorescence imaging using fluorescent calcium indicator (FLIPR) with activity expressed as a percentage of a maximal, $10 \mathrm{nM}$ ghrelin response. (B) Antagonist effects - cells were treated with various concentrations of [D-Lys-3]-GHRP-6 $(\diamond)$, compound A $(\boldsymbol{\square})$, or compound B $(\Delta)$ prior to stimulation with ghrelin. Their effects were expressed as percent inhibition of maximal ghrelin response $(10 \mathrm{nM})$. A representative of at least two independent experiments is shown with triplicate measurements at each peptide concentration.

of ghrelin-induced increase in $\mathrm{Ca}^{2+}$ flux, with $\mathrm{IC}_{50}$ values of $3 \cdot 86 \mu \mathrm{M}$ and $73 \cdot 1 \mathrm{nM}$ respectively (Fig. 2B). Compound $\mathrm{B}$, a structural homolog of compound $\mathrm{A}$, was also tested and found to be inactive (Fig. 2B). This finding is in agreement with the poor affinity that compound B displayed for GHS-R in a binding assay (data not shown).

\section{$R C-4 B / C .40$ subclone}

The RC-4B/C cells are a heterogeneous population of corticotropic and gonadotropic, as well as somatotropic cells. While it has been possible to evaluate GHS-R agonists and antagonists using the parental cells, further characterization of ghrelin signaling is complicated by the presence of these other cell types. Another factor limiting the utility of the parental RC-4B/C cells has been the greatly diminished or even loss of ghrelin responsiveness routinely observed after only ten culture passages. Consequently, an effort to identify a stable subclone was initiated which resulted in the screening of 60 subclones displaying various morphologies. Among these, clone 40 (RC-4B/C.40) demonstrated a significantly more robust ghrelin response in the $\mathrm{Ca}^{2+}$ mobilization assay that was more stable over multiple passages compared with the parental $\mathrm{RC}-4 \mathrm{~B} / \mathrm{C}$ cells (Fig. 3). Thus, the subclone RC-4B/C.40 was selected for further ghrelin signaling studies. RTqPCR analysis indicated that GHS-R mRNA expression is approximately twofold higher in the RC-4B/C.40 cells than in the parental RC-RB/C cells (data not shown).

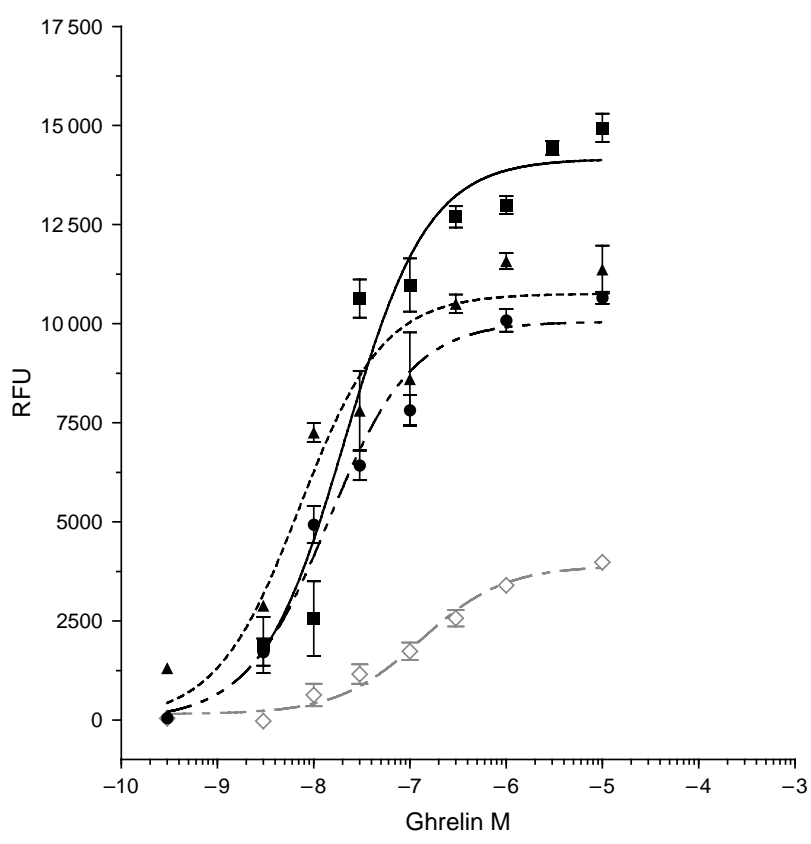

Figure 3 Ghrelin dose-response in multiple passages of the RC-4B/C.40 subclone versus the parental RC-4B/C cells. Ghrelin dose-response curves for separate passages of the subclone $\mathrm{RC}-4 \mathrm{~B} / \mathrm{C} .40$ cells are depicted (P.5 cells, $\mathrm{EC}_{50}=21 \cdot 2 \mathrm{nM}$, solid line; P.9 cells, $\mathrm{EC}_{50}=7 \cdot 2 \mathrm{nM}$, $\Delta$ dotted line; and P.12 cells, $\mathrm{EC}_{50}=14.3 \mathrm{nM}$, dashed line). A representative ghrelin dose-response for the parental RC-4B/C cells ( $P .7$ cells, $\mathrm{EC}_{50}=109 \mathrm{nM}, \diamond$ dashed gray line) is shown for comparison. $\mathrm{RFU}$, relative fluorescence units. 
As observed in the parental cells (Fig. 2), treatment of the RC-4B/C. 40 cells with both rat ghrelin and the related peptide agonist hexarelin resulted in robust, dose-dependent responses, yielding $\mathrm{EC}_{50}$ values of $5 \cdot 5$ and $2.7 \mathrm{nM}$ respectively (Fig. 4A). Treatment with desoctanoyl rat ghrelin did not elicit a signal at any dose of peptide, indicating that the $\mathrm{RC}-4 \mathrm{~B} / \mathrm{C} .40$ cells respond specifically to active ghrelin (Fig. 4A). The RC-4B/C.40 cells were also treated with the peptidic GHS-R antagonist [D-Lys3] GHRP-6 as well as the small molecule inhibitor, compound $\mathrm{A}$, and its inactive analog, compound $\mathrm{B}$ (Fig. 4B). Both [D-Lys3] GHRP-6 and the small molecule compound A effectively inhibited the $10 \mathrm{nM}$ ghrelin response, with $\mathrm{IC}_{50}$ values of $4.09 \mu \mathrm{M}$ and $195 \mathrm{nM}$ respectively, while compound $\mathrm{B}$ was inactive, with an $\mathrm{IC}_{50}>10 \mu \mathrm{M}$ (Fig. 4B). Again, the results for [D-Lys3] GHRP-6 agree well with literature-reported values and the effects of all three agents in the RC-4B/C.40 cells are similar to the effects observed in both the parental RC-4B/C cells (Fig. 2B) and the CHO-K cells that stably overexpress human GHS-R (data not shown).

\section{Characterization of ghrelin $\mathrm{Ca}^{2+}$ signaling in the subclone $R C-4 B / C .40$ cells}

In order to further characterize ghrelin signaling in the RC-4B/C.40 subclone, we pretreated cells with Ptx, which specifically inhibits $G_{i}$ and $G_{o}$ coupling, or with the PLC inhibitor U-73122, which blocks the signal downstream of $G_{q}$ activation that ultimately causes the rise of $\left[\mathrm{Ca}^{2+}\right]_{\mathrm{i}}$ measured in FLIPR. Pretreatment with $1 \mu \mathrm{g} / \mathrm{ml} \mathrm{Ptx}$ for $4 \mathrm{~h}$ at $37^{\circ} \mathrm{C}$ did not affect the ghrelin dose-response, although the maximal signal attained was slightly higher (Fig. 5A). On the other hand, pretreatment with $1 \mu \mathrm{M}, 3 \mu \mathrm{M}$, and $10 \mu \mathrm{M}$ U-73122 resulted in a dose-dependent inhibition of the ghrelin response (Fig. 5B). Taken together, these results suggest that ghrelin signaling in RC-4B/C.40 cells occurs primarily through $\mathrm{G}_{\mathrm{q}}$ and not $\mathrm{G}_{\mathrm{i}}$ or $\mathrm{G}_{\mathrm{o}}$ coupling.

We next determined the relative contributions of extracellular $\mathrm{Ca}^{2+}$ influx and release of $\mathrm{Ca}^{2+}$ from intracellular stores in the ghrelin-induced $\mathrm{Ca}^{2+}$ signal. RC-4B/C. 40 cells were stimulated with $3 \mathrm{nM}$ and $100 \mathrm{nM}$ ghrelin in either the presence or absence of extracellular $\mathrm{Ca}^{2+}$. The ghrelin response in the presence of extracellular $\mathrm{Ca}^{2+}$ was of greater magnitude (with a peak signal $22 \%$ greater than the signal without extracellular $\mathrm{Ca}^{2+}$ ) and sustained duration (with approximately $50 \%$ of the signal remaining at $300 \mathrm{~s}$ after ghrelin stimulation) than that observed in the absence of extracellular $\mathrm{Ca}^{2+}$ (Fig. 6A). To further demonstrate the role of extracellular $\mathrm{Ca}^{2+}$ in ghrelin signaling, we treated cells with the L-type channel blocker, nifedipine. Pretreatment with $100 \mu \mathrm{M}$ nifedipine in the presence of extracellular $\mathrm{Ca}^{2+}$ resulted in a $43 \%$ reduction of the ghrelin-induced rise in $\left[\mathrm{Ca}^{2+}\right]_{\mathrm{i}}$ as compared with the untreated cells (Fig. 6B). Next, to address the role of $\mathrm{Ca}^{2+}$ release from intracellular stores in the ghrelin signal, we treated cells with thapsigargin. Thapsigargin causes the release of $\mathrm{Ca}^{2+}$ from
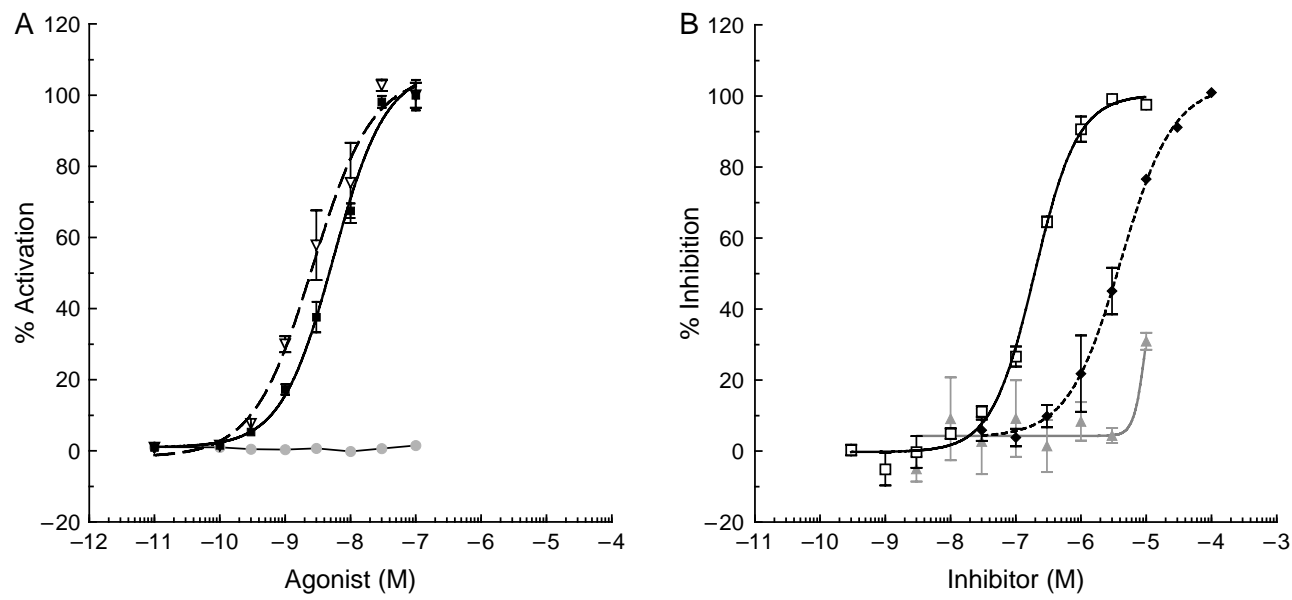

Figure 4 Effects of GHS-R agonists and antagonists on the subclone RC-4B/C.40 cells. (A) Agonist treatment: cells were treated with various concentrations (half-log dose increments ranging from $0 \cdot 01$ to $100 \mathrm{nM}$ ) of rat ghrelin $(\boldsymbol{\square})$, hexarelin $(\nabla)$, and des-octanoyl rat ghrelin (o). (B) Antagonist treatment: RC$4 \mathrm{~B} / \mathrm{C} .40$ cells were treated with various, half-log concentrations (ranging from $0.3 \mathrm{nM}$ to $100 \mu \mathrm{M}$ ) of the peptide antagonist [D-Lys3] GHRP-6, the small molecule compound A, and the structurally related analog, compound B. Both [D-Lys3] GHRP-6 ( $\bullet$, dashed line) and the small molecule compound A ( $\square$, solid line) dose dependently inhibited the $10 \mathrm{nM}$ ghrelin response ( $\mathrm{IC}_{50} \mathrm{~S}$ of $4.09 \mu \mathrm{M}$ and $195 \mathrm{nM}$ respectively) while compound $B\left(\Delta\right.$, solid line) was essentially inactive $\left(\mathrm{IC}_{50}>10 \mu \mathrm{M}\right)$. The results shown are representative of at least two independent experiments with triplicate measurements at each peptide concentration. 

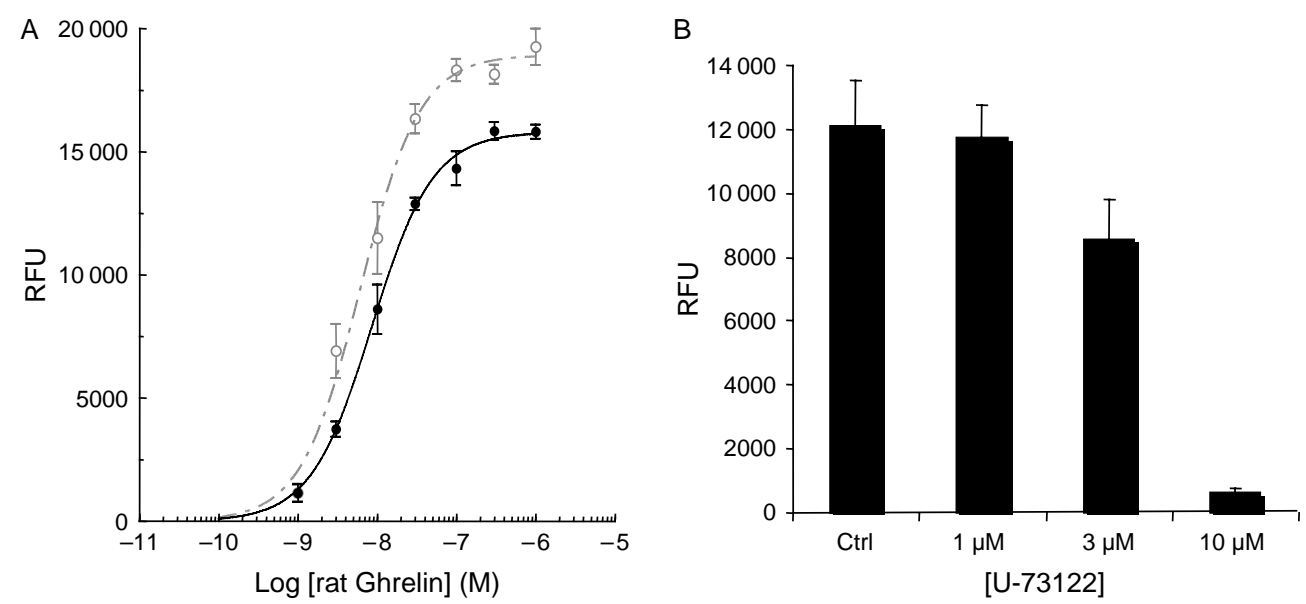

Figure 5 Effects of Ptx and PLC inhibitor U-73122 on ghrelin signaling in RC-4B/C.40 cells. (A) Pretreatment with $1 \mu \mathrm{g} / \mathrm{ml}$ Ptx for $4 \mathrm{~h}$ showed no effects on the ghrelin dose-response (o, dashed line) compared with the untreated control dose-response ( $\bullet$, solid line), with $\mathrm{EC}_{50} \mathrm{~s}$ of 6.15 and $8.56 \mathrm{nM}$ respectively. (B) Pretreatment with 1, 3, and $10 \mu \mathrm{M}$ PLC inhibitor U-73122 resulted in dose-dependent inhibition of a $10 \mathrm{nM}$ ghrelin response, with $>90 \%$ inhibition observed at the maximum $10 \mu \mathrm{M}$ dose. Ctrl, control; RFU, relative fluorescence units.

intracellular stores and prevents re-uptake into the endoplasmic reticulum (ER). Pretreatment with $1 \mu \mathrm{M}$ thapsigargin was shown to effectively block the ghrelin response in the absence of extracellular $\mathrm{Ca}^{2+}$ (Fig. 7). This effect, however, was not observed in the presence of extracellular $\mathrm{Ca}^{2+}$, possibly reflecting the drive to restore intracellular $\mathrm{Ca}^{2+}$ tone (Fig. 7). Together, these results suggest that the ghrelin-induced rise of $\left[\mathrm{Ca}^{2+}\right]_{\mathrm{i}}$ involves an initial release from intracellular stores followed by an influx through L-type $\mathrm{Ca}^{2+}$ channels that contributes to both the magnitude and sustained duration of the signal.

\section{Constitutive activity of GHS-R in RC-4B/C.40 and CHO-hGHS-R cells}

The constitutive activity of GHS-R in the RC-4B/C.40 and the recombinant CHO-hGHS-R cells was evaluated
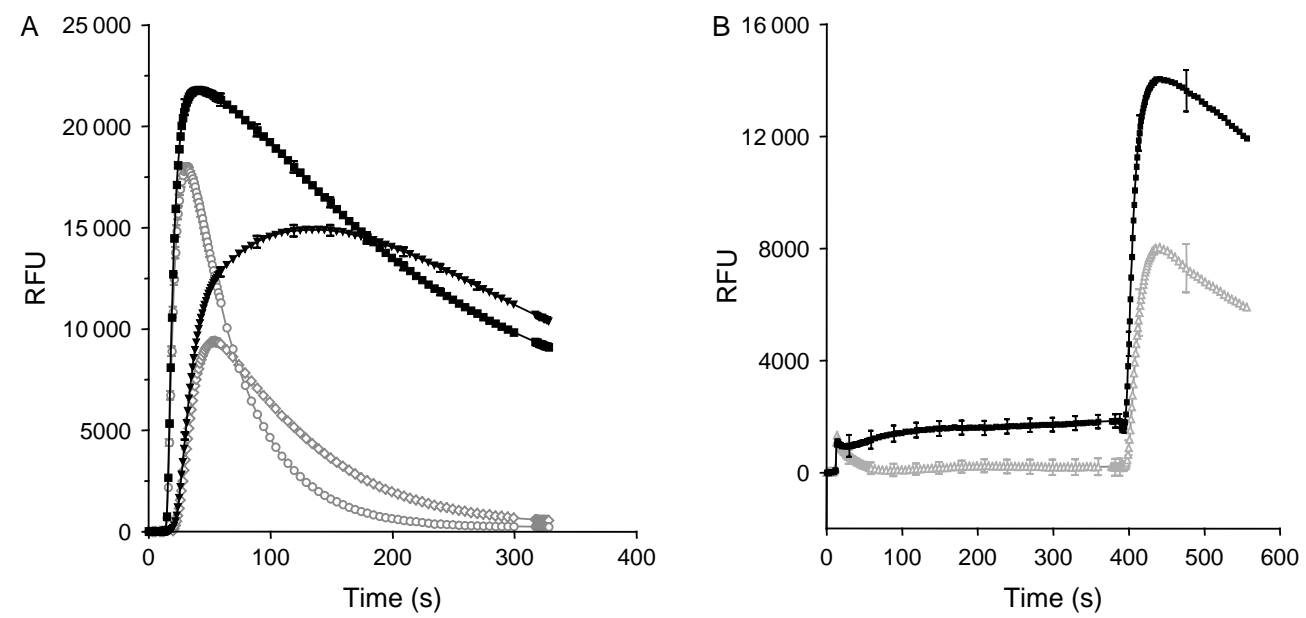

Figure 6 Ghrelin signaling in RC-4B/C.40 cells in the presence and absence of extracellular $\mathrm{Ca}^{2+}$ and following pretreatment with the L-type channel blocker nifedipine. (A) Representative $\mathrm{Ca}^{2+}$ signal tracings measured in FLIPR are shown following stimulation with $3 \mathrm{nM}$ ghrelin $(\boldsymbol{\Delta})$ and $100 \mathrm{nM}$ ghrelin $(\boldsymbol{\square})$ in the presence of extracellular $\mathrm{Ca}^{2+}$, and for $3 \mathrm{nM}$ ghrelin $(\diamond)$ and $100 \mathrm{nM}$ ghrelin $(O)$ in the absence of extracellular $\mathrm{Ca}^{2+}$. (B) Effects of pretreatment with $100 \mu \mathrm{M}$ nifedipine on the $10 \mathrm{nM}$ ghrelin response are shown. The $\mathrm{Ca}^{2+}$ signal tracing for the untreated, control cells is shown as a black line with solid black squares $(\mathbf{D})$. The signal tracing for the ghrelin response following pretreatment with $100 \mu \mathrm{M}$ nifedipine is shown as a gray line with open gray triangles $(\Delta)$. RFU, relative fluorescence units. 


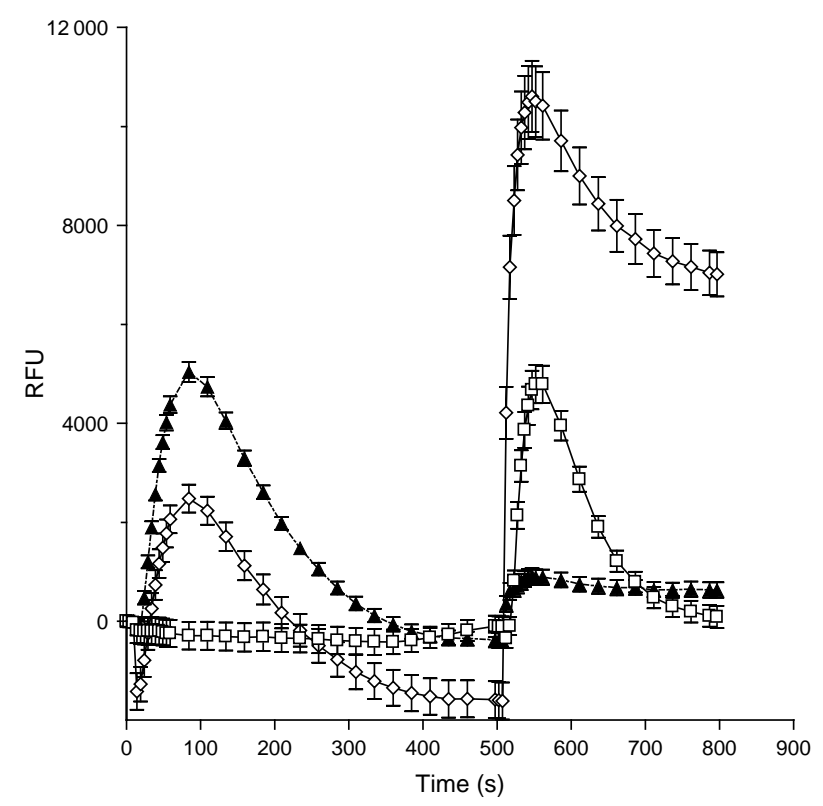

Figure 7 Ghrelin response in the absence and presence of extracellular $\mathrm{Ca}^{2+}$ following pretreatment with $1 \mu \mathrm{M}$ thapsigargin in RC-4B/C. 40 cells. Control cells were incubated in the absence of extracellular $\mathrm{Ca}^{2+}$ for 6 min and then stimulated with $3 \mathrm{nM}$ ghrelin in the continued absence of $\mathrm{Ca}^{2+}(\square)$ for $5 \mathrm{~min}$. Cells pretreated with $1 \mu \mathrm{M}$ thapsigargin were incubated in the absence of extracellular $\mathrm{Ca}^{2+}$ for 6 min followed by stimulation with $3 \mathrm{nM}$ ghrelin in either the continued absence of $\mathrm{Ca}^{2+}(\boldsymbol{\Delta})$ or with extracellular $\mathrm{Ca}^{2+}$ restored $(\diamond)$ for $5 \mathrm{~min}$. For clarity, every 5 th timepoint for the FLIPR assay is shown; Mean \pm s.D.; $n=8$. RFU, relative fluorescence units.

using a PI hydrolysis assay that measures the accumulation of $\left[{ }^{3} \mathrm{H}\right]$ inositol phosphates from $\left[{ }^{3} \mathrm{H}\right]$ myoinositol turnover. In accordance with the G-protein coupled receptor (GPCR) signaling paradigm, ghrelin or basal
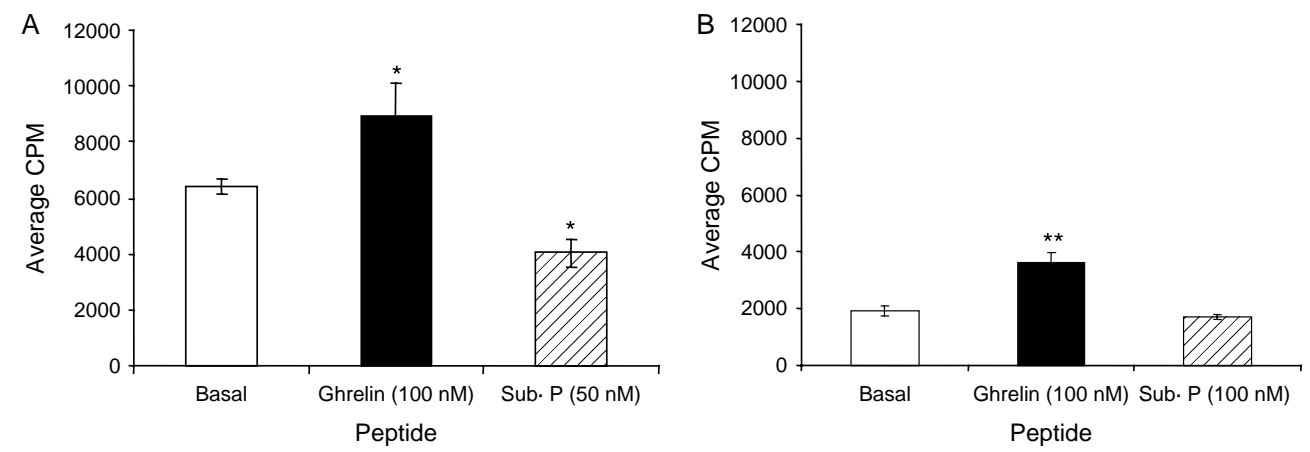

Figure 8 Constitutive activity of GHS-R in the RC-4B/C.40 and the CHO-hGHS-R cells using phosphatidylinositol (PI) hydrolysis. (A) $\left[{ }^{3} \mathrm{H}\right]$ Inositol phosphate production in the CHO-hGHS-R cells under basal conditions (white bar), following stimulation with $100 \mathrm{nM}$ ghrelin (solid black bar), and after treatment with $50 \mathrm{nM}\left[\mathrm{D}-\mathrm{Arg}^{1}, \mathrm{D}-\mathrm{Phe}^{5}, \mathrm{D}-\mathrm{Trp}^{7,9}\right.$, Leu $\left.{ }^{11}\right]$-substance $\mathrm{P}$ analog (black cross-hatched bar). (B) $\left[{ }^{3} \mathrm{H}\right]$ Inositol phosphate production in the RC-4B/C.40 cells under basal conditions (white bar), following stimulation with $100 \mathrm{nM}$ ghrelin (solid black bar), and following treatment with $100 \mathrm{nM}$ [D-Arg ${ }^{1}, \mathrm{D}-\mathrm{Phe}^{5}$, $\mathrm{D}-\mathrm{Trp}^{7,9}$, Leu ${ }^{11}$ ]-substance $\mathrm{P}$ analog (black cross-hatched bar). These data are representative of at least three separate experiments, showing mean CPMs \pm S.D. for each treatment condition. Statistical analysis was carried out using Student's $t$-test. * $P<0.05$ compared with basal inositol phosphate levels in $\mathrm{CHO}$ hGHS-R cells. ${ }^{\star *} P<0.05$ compared with basal inositol phosphate levels in RC-4B/C.40 cells. 
be found in the pituitary and hypothalamus. Indeed, GHS-R was first characterized in the plasma membrane fraction of pituitary and hypothalamic tissue by binding of $\left[{ }^{35} \mathrm{~S}\right] \mathrm{MK} 0677$, a small molecule GHS (Smith et al. 1997). Subsequently, the expression of GHS-R and ghrelin, by then its newly identified natural ligand, was demonstrated in the normal and abnormal human pituitary using RT-PCR (Korbonits et al. 1998, 2001). Furthermore, recent studies involving double immunofluorescence localized ghrelin in specific cell populations contained within the rat anterior pituitary. It is expressed in somatotrophs, lactotrophs and thyrotrophs, but not in the corticotrophs or gonadotrophs (Caminos et al. 2003). GHS-R mRNA expression has also been shown to be the highest in human somatotroph tumors and essentially non-detectable in gonadotroph tumors (Korbonits et al. 2001). As the expression and function of ghrelin and its receptor in the anterior pituitary is well established, we investigated whether a tumor cell line derived from the pituitary could be used as a routine reagent for measurements of GHS-R activity in vitro. The $\mathrm{RC}-4 \mathrm{~B} / \mathrm{C}$ cell line was established in The Jackson Laboratory (Bar Harbor, ME, USA) from an aged male rat with pituitary adenoma. It is a heterogeneous cell line containing all known anterior pituitary hormone-secreting cell types as demonstrated by immunocytochemistry (Hurbain-Kosmath et al. 1990). We demonstrate here using RT-PCR that RC-4B/C cells express GHS-Rla mRNA.

The elucidation of the second messenger system involved in GHS-R signaling is an area of great interest. Earlier studies involving activation of GHS-R by artificial GHSs showed a variety of responses such as an increase in intracellular cAMP and free $\mathrm{Ca}^{2+}$ levels as well as activation of PKA and PKC (Chen 2000). Recently, the ghrelin-stimulated GHS-R signal transduction pathway has been investigated in isolated porcine somatotrophs. It was shown that ghrelin increased the $\left[\mathrm{Ca}^{2+}\right]_{\mathrm{i}}$ in $98 \%$ of the cells that responded to GHRH, an effect that was decreased in the presence of a GHS-R peptidic antagonist [D-Lys-3]-GHRP-6 (Glavaski-Joksimovic et al. 2003). In addition, another report demonstrated a ghrelin dose-dependent increase in the $\left[\mathrm{Ca}^{2+}\right]_{i}$ in ratderived single hypothalamic neuropeptide Y-neurons, known for their critical role in the stimulation of food intake (Kohno et al. 2003).

Ghrelin and hexarelin have previously been shown to be equipotent in a binding assay using pituitary membrane preparations (Muccioli et al. 2001). We show here that ghrelin and hexarelin, a non-natural peptidyl GHS (Arvat et al. 2001), activated GHS-R in RC-4B/C cells with similar potency, as judged by an increase in the $\left[\mathrm{Ca}^{2+}\right]_{\mathrm{i}}$. Their $\mathrm{EC}_{50}$ values in $\mathrm{RC}-4 \mathrm{~B} / \mathrm{C}$ cells are comparable to those obtained using $\mathrm{CHO}$ cells overexpressing GHS-R (data not shown). In contrast, des-octanoyl ghrelin, a precursor that is devoid of the endocrine activity of acylated ghrelin (Broglio et al. 2003), had no effect on the $\left[\mathrm{Ca}^{2+}\right]_{\mathrm{i}}$ in RC-4B/C cells. In addition, antagonists of GHS-R blocked the ghrelininduced increase in $\left[\mathrm{Ca}^{2+}\right]_{\mathrm{i}}$. Compound $\mathrm{A}$ was more potent than [D-Lys-3]-GHRP-6, consistent with their relative affinities for GHS-R in a radiolabeled ghrelin binding assay using membrane preparations of $\mathrm{CHO}$ cells overexpressing GHS-R (data not shown). Compound B, a structural homolog of compound A but with a weak binding affinity for GHS-R, was inactive in the $\left[\mathrm{Ca}^{2+}\right]_{\mathrm{i}}$ flux assay.

While effective as an in vitro tool for screening GHS-R pharmacophores, the $\mathrm{RC}-4 \mathrm{~B} / \mathrm{C}$ cells proved to be unsuitable for further characterization of ghrelin signal transduction, possibly due to being a heterogeneous cell population. Moreover, a consistent pattern of diminished ghrelin responsiveness during cell culture was observed, which further limited their utility as an in vitro screening tool. In an attempt to overcome these limitations, a subclone RC-4B/C.40, was generated. It demonstrated the most stable and highest magnitude of ghrelin response compared with both the parental RC- $4 \mathrm{~B} / \mathrm{C}$ cells and other subclones. Like the parental cells, RC-4B/C.40 cells showed a robust response to both rat ghrelin and the peptide agonist hexarelin, while no response was observed with des-octanoyl ghrelin treatment. Likewise, treatment with the peptide antagonist [D-Lys3]-GHRP-6 or the small molecule inhibitor, compound A, effectively blocked the ghrelin response, while the structural analog, compound $\mathrm{B}$, was essentially inactive.

A number of reports have identified molecules potentially involved in the ghrelin-induced $\mathrm{Ca}^{2+}$ signaling pathway. For example, using enzyme inhibitors, it was shown that adenylyl cyclase and PLC are involved in GHS-R signaling in somatotropes (Glavaski-Joksimovic et al. 2003), and PKA in the hypothalamic neurons (Kohno et al. 2003). Using calcium channel blockers, it was also demonstrated that L-type channels are essential for $\mathrm{Ca}^{2+}$ influx in somatotropes (Glavaski-Joksimovic et al. 2003) and $\mathrm{N}$-type channels in hypothalamic neurons (Kohno et al. 2003). As a homogeneous cell population, the RC-4B/C.40 subclone provided the means to investigate ghrelin signal transduction. We demonstrate here that treatment with Ptx, which inhibits $G_{i}$ and $G_{o}$ coupling, had no effect on the ghrelin signal, while pretreatment with the PLC inhibitor U-73122 dose-dependently blocked the ghrelin signal in RC4B/C.40 cells, suggesting that signaling occurs primarily through $\mathrm{G}_{\mathrm{q}}$ coupling, as expected. We also demonstrated that the ghrelin-induced $\left[\mathrm{Ca}^{2+}\right]_{\mathrm{i}}$ flux in RC-4B/C.40 cells is dependent on both influx of extracellular $\mathrm{Ca}^{2+}$, consistent with observations in isolated somatotropes, and release from intracellular stores. Removal of $\mathrm{Ca}^{2+}$ from the cell medium 
greatly reduced the overall magnitude and duration of the ghrelin-induced increase in $\left[\mathrm{Ca}^{2+}\right]_{i}$, as did incubation with the L-type channel blocker nifedipine, indicating the involvement of calcium channels in the ghrelin response. The release of intracellular $\mathrm{Ca}^{2+}$ stores by thapsigargin also effectively blocked the ghrelin response in the absence of extracellular $\mathrm{Ca}^{2+}$. Taken together, these observations indicate that ghrelin signaling through GHS-R involves the release of $\mathrm{Ca}^{2+}$ from intracellular stores as well as influx of extracellular $\mathrm{Ca}^{2+}$ through plasma membrane ion channels.

Recent studies involving GHS-R expression in recombinant cell systems have reported a high degree of constitutive activity, similar to that observed with several other GPCRs, including the neurotensin receptor 2 (NT-R2) and the viral ORF-74 receptor (Holst et al. 2003, Holst \& Schwartz 2004). Using inositol phosphate turnover and a cAMP response element-dependent transcriptional reporter assay to assess constitutive activity, Schwartz and colleagues demonstrated that GHS-R transiently expressed in COS-7 and HEK 293 cells signals at about $50 \%$ maximal activation in the absence of ghrelin (Holst et al. 2003). Stimulation with ghrelin results in a twofold increase in activity, while treatment with the inverse agonist $\left[\mathrm{D}-\mathrm{Arg}^{1}, \mathrm{D}-\mathrm{Phe}^{5}, \mathrm{D}-\mathrm{Tryp}^{7,9}\right.$, Leu $^{11}$ ]-substance P analog potently suppresses basal activity. The constitutive activity of GHS-R in these recombinant cell systems may be an artifact of receptor overexpression. However, the structurally homologous motilin receptor does not show measurable constitutive activity when expressed in a recombinant system, suggesting that high constitutive activity may in fact be an intrinsic, physiologically relevant property of GHS-R (Holst et al. 2003, Holst \& Schwartz 2004).

We decided to investigate the constitutive activity of GHS-R in the RC-4B/C.40 cells using a PI hydrolysis assay and compare it with the level of activity in the recombinant CHO-hGHS-R cells. The CHO-hGHS-R cells exhibited a high degree of constitutive activity, which was reduced upon treatment with the inverse agonist $\left[\mathrm{D}-\mathrm{Arg}^{1}, \mathrm{D}-\mathrm{Phe}^{5}, \mathrm{D}-\operatorname{Tryp}^{7,9}\right.$, Leu $\left.^{11}\right]$-substance P analog, in agreement with the effects observed in other recombinant cell systems (Holst et al. 2003, 2004, Holst \& Schwartz 2004). In contrast, the RC-4B/C.40 cells showed little, if any, constitutive activity. The basal inositol phosphate level was threefold less than in the $\mathrm{CHO}$ cells and was not further reduced by treatment with the inverse agonist [D-Arg ${ }^{1}, \mathrm{D}-\mathrm{Phe}^{5}, \mathrm{D}^{5}$-Tryp ${ }^{7,9}$, Leu $\left.{ }^{11}\right]$-substance P analog.

Thus, the endogenously expressed GHS-R in RC4B/C.40 cells does not exhibit constitutive activity in our hands. As this runs counter to what has recently been reported in several recombinant cell lines, our observations raise important questions as to the physiological relevance of GHS-R constitutive activity. A possible explanation for the disparity between the levels of constitutive activity in the recombinant $\mathrm{CHO}$ line versus the RC-4B/C.40 cells is the presence of an intracellular regulator of GHS-R signaling, which functions to suppress GHS-R constitutive activity. Presumably, such an intracellular regulator would not be expressed in the recombinant CHO-hGHS-R line where its absence may account for the high level of constitutively active GHS-R observed, while a more physiologically relevant pituitary cell line, RC-4B/C, may express the regulator, accounting for the low level of constitutive activity in this cell line. Alternatively, as with the MC-4 receptor, where AgRP functions as an inverse agonist, there may be an unidentified endogenous inverse agonist that attenuates GHS-R constitutive activity and may play a critical role in mediating the effects on the complex network of neuroendocrine inputs to ghrelin effector cells (Nijenhuis et al. 2001, Holst et al. 2003). However, such an endogenous inverse agonist would most likely only be observed in an in vivo setting and not in a homogeneous cell population in vitro. Nonetheless, the RC-4B/C.40 cells may ultimately provide a more relevant cell line in which to model and investigate ghrelin signaling than what can be currently achieved using recombinant GHS-R cell systems.

In conclusion, we have identified a suitable cell line for GHS-R pharmacology and signaling studies. The rat anterior pituitary RC-4B/C cells express endogenous GHS-R that responds to ghrelin as judged by increased $\left[\mathrm{Ca}^{2+}\right]_{\mathrm{i}}$. GHS-R antagonists blocked the ghrelin response with the anticipated rank order of potency. Additionally, we were able to identify and characterize a subclone, RC-4B/C.40, which demonstrated a more robust and stable ghrelin response than that observed in the parental cells. Along with showing agonist and antagonist effects similar to those observed in the parental RC-4B/C cells and in CHO-hGHS-R cells, the RC-4B/C.40 subclone also provided the means to more fully characterize ghrelin signaling. The mechanism of ghrelin-induced increase in $\left[\mathrm{Ca}^{2+}\right]_{\mathrm{i}}$ in the RC-4B/C.40 cells involves $\mathrm{G}_{\mathrm{q}}$ coupling along with both extracellular $\mathrm{Ca}^{2+}$ flux and release of $\mathrm{Ca}^{2+}$ from intracellular stores. The lack of constitutive activity of GHS-R in RC-4B/C.40 cells indicates that GHS-R functions differently in this more physiologically relevant cell type than in recombinant cell lines. Thus, the RC- $4 \mathrm{~B} / \mathrm{C}$ parental and RC-4B/C.40 cell lines described here represent useful in vitro tools for the identification of GHS-R agonists or antagonists with potential therapeutic applications in the treatment of growth hormone deficiency or body weight disorders, and, more significantly, for examination of the mechanism of GHS-R activation and signaling, including the basis of constitutive activity. 


\section{Acknowledgements}

We thank Dr Paul Richardson for the synthesis of ghrelin, Dr Gang Liu and his group for the synthesis of compounds A and B, Rich Janis for the design of RT-PCR primers, Dr Timothy Esbenshade for helpful advice and discussions, and Dr Hing Sham for guidance. The authors declare that there is no conflict of interest that would prejudice the impartiality of this scientific work.

\section{References}

Adams EF, Huang B, Buchfelder M, Howard A, Smith RG, Feighner SD, van der Ploeg LH, Bowers CY \& Fahlbusch R 1998 Presence of growth hormone secretagogue receptor messenger ribonucleic acid in human pituitary tumors and rat GH3 cells. Journal of Clinical Endocrinology and Metabolism 83 638-642.

Arvat E, Maccario M, di Vito L, Broglio F, Benso A, Gottero C, Papotti M, Muccioli G, Dieguez C, Casanueva FF et al. 2001 Endocrine activities of ghrelin, a natural growth hormone secretagogue (GHS), in humans: comparison and interactions with hexarelin, a nonnatural peptidyl GHS, and GH-releasing hormone. Journal of Clinical Endocrinology and Metabolism 86 1169-1174.

Broglio F, Benso A, Gottero C, Prodam F, Gauna C, Filtri L, Arvat E, van der Lely AJ, Deghenghi R \& Ghigo E 2003 Non-acylated ghrelin does not possess the pituitaric and pancreatic endocrine activity of acylated ghrelin in humans. Journal of Endocrinological Investigation 26 192-196.

Caminos JE, Nogueiras R, Blanco M, Seoane LM, Bravo S, Alvarez CV, García Caballero T, Casanueva FF \& Diéguez C 2003 Cellular distribution and regulation of ghrelin messenger ribonucleic acid in the rat pituitary gland. Endocrinology 144 5089-5097.

Chen C 2000 Growth hormone secretagogue actions on the pituitary gland: multiple receptors for multiple ligands? Clinical and Experimental Pharmacology and Physiology 27 323-329.

Cowley MA, Smith RG, Diano S, Tschöp M, Pronchuk N, Grove KL, Strasburger CJ, Bidlingmaier M, Esterman M, Heiman ML et al. 2003 The distribution and mechanism of action of ghrelin in the CNS demonstrates a novel hypothalamic circuit regulating energy homeostasis. Neuron 37 649-661.

Cummings DE, Purnell JQ, Frayo RS, Schmidova K, Wisse BE \& Weigle DS 2001 A preprandial rise in plasma ghrelin levels suggests a role in meal initiation in humans. Diabetes 50 1714-1719.

Date Y, Kojima M, Hosoda H, Sawaguchi A, Mondal MS, Suganuma T, Matsukura S, Kangawa K \& Nakazato M 2000 Ghrelin, a novel growth hormone-releasing acylated peptide, is synthesized in a distinct endocrine cell type in the gastrointestinal tracts of rats and humans. Endocrinology 141 4255-4261.

Date Y, Murakami N, Toshinai K, Matsukura S, Niijima A, Matsuo H, Kangawa K \& Nakazato M 2002 The role of the gastric afferent vagal nerve in ghrelin-induced feeding and growth hormone secretion in rats. Gastroenterology 123 1120-1128.

Ghigo E, Arvat E, Giordano R, Broglio F, Gianotti L, Maccario M, Bisi G, Graziani A, Papotti M, Muccioli G et al. 2001 Biologic activities of growth hormone secretagogues in humans. Endocrine 14 87-93.

Giustina A \& Veldhuis JD 1998 Pathophysiology of the neuroregulation of growth hormone secretion in experimental animals and the human. Endocrine Reviews 19 717-797.

Glavaski-Joksimovic A, Jeftinija K, Scanes CG, Anderson LL \& Jeftinija S 2003 Stimulatory effect of ghrelin on isolated porcine somatotropes. Neuroendocrinology 77 367-379.

Gnanapavan S, Kola B, Bustin SA, Morris DG, Mcgee P, Fairclough P, Bhattacharya S, Carpenter R, Grossman AB \& Korbonits M 2002
The tissue distribution of the mRNA of ghrelin and subtypes of its receptor, GHS-R, in humans. Journal of Clinical Endocrinology and Metabolism 872988.

Holst B \& Schwartz TW 2004 Constitutive ghrelin receptor activity as a signaling set point in appetite regulation. Trends in Pharmacological Sciences 25 113-117.

Holst B, Cygankiewicz A, Jensen TH, Ankersen M \& Schwartz TW 2003 High constitutive signaling of the ghrelin receptor-identification of a potent inverse agonist. Molecular Endocrinology 17 2201-2210.

Holst B, Holliday ND, Bach A, Elling CE, Cox HM \& Schwartz TW 2004 Common structural basis for constitutive activity of the ghrelin receptor family. Journal of Biological Chemistry 279 53806-53817.

Horvath TL, Castañeda T, Tang-Christensen M, Pagotto U \& Tschöp MH 2003 Ghrelin as a potential anti-obesity target. Current Pharmaceutical Design 9 1383-1395.

Howard AD, Feighner SD, Cully DF, Arena JP, Liberator PA, Rosenblum CI, Hamelin M, Hreniuk DL, Palyha OC, Anderson J et al. $1996 \mathrm{~A}$ receptor in pituitary and hypothalamus that functions in growth hormone release. Science 273 974-977.

Hurbain-Kosmath I, Berault A, Noel N, Polkowska J, Bohin A, Jutisz M, Leiter EH, Beamer WG, Bedigian HG, Davisson MT et al. 1990 Gonadotropes in a novel rat pituitary tumor cell line, RC-4B/C. Establishment and partial characterization of the cell line. In Vitro Cellular and Developmental Biology 26 431-440.

Kim SK, Yoon CY, Jang PG, Park YJ, Shin CS, Park HS, Ryu JW, Pak YK, Park JY, Lee KU et al. 2004 The mitogenic and antiapoptotic actions of ghrelin in 3T3-L1 adipocytes. Molecular Endocrinology 18 2291-2301.

Kohno D, Gao Hong Z, Muroya S, Kikuyama S \& Yada T 2003 Ghrelin directly interacts with neuropeptide Y-containing neurons in the rat arcuate nucleus: $\mathrm{Ca}^{2+}$ signaling via protein kinase $\mathrm{A}$ and $\mathrm{N}$-type channel-dependent mechanisms and cross-talk with leptin and orexin. Diabetes 52 948-956.

Kojima M, Hosoda H, Date Y, Nakazato M, Matsuo H \& Kangawa K 1999 Ghrelin is a growth-hormone-releasing acylated peptide from stomach. Nature 402 656-660.

Korbonits M, Jacobs RA, Aylwin SJ, Burrin JM, Dahia PL, Monson JP, Honegger J, Fahlbush R, Trainer PJ, Chew SL et al. 1998 Expression of the growth hormone secretagogue receptor in pituitary adenomas and other neuroendocrine tumors. Journal of Clinical Endocrinology and Metabolism $\mathbf{8 3}$ 3624-3630.

Korbonits M, Bustin SA, Kojima M, Jordan S, Adams EF, Lowe DG, Kangawa K \& Grossman AB 2001 The expression of the growth hormone secretagogue receptor ligand ghrelin in normal and abnormal human pituitary and other neuroendocrine tumors. Journal of Clinical Endocrinology and Metabolism 86 881-887.

Masuda Y, Tanaka T, Inomata N, Ohnuma N, Tanaka S, Itoh Z, Hosoda H, Kojima M \& Kangawa K 2000 Ghrelin stimulates gastric acid secretion and motility in rats. Biochemical and Biophysical Research Communication 276 905-908.

Muccioli G, Papotti M, Locatelli V, Ghigo E \& Deghenghi R 2001 Binding of ${ }^{125}$ I-labeled ghrelin to membranes from human hypothalamus and pituitary gland. Journal of Endocrinological Investigation 24 RC7-RC9.

Nanzer AM, Kalaf S, Mozid AM, Fowkes RC, Patel MV, Burrin JM, Grossman AB \& Korbonits M 2004 Ghrelin exerts a proliferative effect on a rat pituitary somatotroph cell line via the mitogenactivated protein kinase pathway. European Journal of Endocrinology 151 233-240.

Nijenhuis WA, Oosterom J \& Adan RA 2001 AgRP(83-132) acts as an inverse agonist on the human-melanocortin-4 receptor. Molecular Endocrinology 15 164-171.

Peino R, Baldelli R, Rodriguez-Garcia J, Rodriguez-Segade S, Kojima M, Kangawa K, Arvat E, Ghigo E, Dieguez C \& Casanueva FF 2000 Ghrelin-induced growth hormone secretion in humans. European Journal of Endocrinology 143 R11-R14. 
Saito N, Konishi K, Takeda H, Kato M, Sugiyama T \& Asaka M 2003 Antigen retrieval trial for post-embedding immunoelectron microscopy by heating with several unmasking solutions. Journal of Histochemistry and Cytochemistry 51 989-994.

Skinner MM, Nass R, Lopes B, Laws ER \& Thorner MO 1998 Growth hormone secretagogue receptor expression in human pituitary tumors. Journal of Clinical Endocrinology and Metabolism 83 4314-4320.

Smith RG, Pong SS, Hickey G, Jacks T, Cheng K, Leonard R, Cohen CJ, Arena JP, Chang CH, Drisko J et al. 1996 Modulation of pulsatile GH release through a novel receptor in hypothalamus and pituitary gland. Recent Progress in Hormone Research 51 261-285.

Smith RG, van der Ploeg LH, Howard AD, Feighner SD, Cheng K, Hickey GJ, Wyvratt MJ Jr, Fisher MH, Nargund RP \& Patchett AA 1997 Peptidomimetic regulation of growth hormone secretion. Endocrine Reviews 18 621-645.

Takaya K, Ariyasu H, Kanamoto N, Iwakura H, Yoshimoto A, Harada M, Mori K, Komatsu Y, Usui T, Shimatsu A et al. 2000 Ghrelin strongly stimulates growth hormone release in humans. Journal of Clinical Endocrinology and Metabolism 85 4908-4911.
Tschöp M, Smiley DL \& Heiman ML 2000 Ghrelin induces adiposity in rodents. Nature 407 908-913.

Volante M, Allìa E, Gugliotta P, Funaro A, Broglio F, Deghenghi R, Muccioli G, Ghigo E \& Papotti M 2002 Expression of ghrelin and of the GH secretagogue receptor by pancreatic islet cells and related endocrine tumors. Journal of Clinical Endocrinology and Metabolism 87 $1300-1308$

Wren AM, Seal LJ, Cohen MA, Brynes AE, Frost GS, Murphy KG, Dhillo WS, Ghatei MA \& Bloom SR 2001 Ghrelin enhances appetite and increases food intake in humans. Journal of Clinical Endocrinology and Metabolism 865992.

Received in final form 28 February 2006

Accepted 4 April 2006 